\title{
ANALISIS EFEKTIFITAS DAN KONTRIBUSI PAJAK HOTEL DAN PAJAK RESTORAN TERHADAP PENDAPATAN ASLI DAERAH (PAD) KOTA BENGKULU
}

\author{
Yun Fitriano ${ }^{1)}$; Zahrah Indah Ferina ${ }^{2)}$ \\ 1) Study Program of Accounting Faculty of Economic, \\ Universitas Dehasen Bengkulu \\ 2) Department of Accounting Faculty of Economic, Universitas Dehasen Bengkulu \\ Email: ${ }^{1)}$ yun.fitriano@gmail.com
}

How to Cite :

Fitriano, Y. dkk. (2020). ANALISIS EFEKTIFITAS DAN KONTRIBUSI PAJAK HOTEL DAN PAJAK RESTORAN TERHADAP PENDAPATAN ASLI DAERAH (PAD) KOTA BENGKULU. EKOMBIS REVIEW: Jurnal Ilmiah Ekonomi Dan Bisnis, 9 (1). DOI: https://doi.org/10.37676/ekombis.v9i1.69-80.

\section{ARTICLE HISTORY}

Received [23 November 2020]

Revised (17 December 2020]

Accepted [21 January 2021]

\section{KEYWORDS}

Effectiveness,

Contribution, Hotel Tax, Restaurant $\operatorname{Tax}$

Original Local

Government Revenue

This is an open access article under the $C C-B Y$-SA license

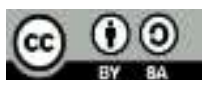

\section{ABSTRAK}

Penelitian ini bertujuan untuk mengetahui sejauh mana efektifitas dan kontribusi dari pajak hotel dan pajak restoran terhadap pendapatan asli daerah (PAD) kota Bengkulu. Data yang digunakan dalam penelitian ini adalah data sekunder pajak hotel dan pajak restoran yang bersumber dari laporan realisasi anggaran pendapatan dan belanja daerah kota Bengkulu tahun 2015 sampai dengan 2018. Metode analisis dalam penelitian ini menggunakan analisis deskriptif kuantitatif. Hasil Penelitian menunjukkan bahwa nilai rata-rata tingkat efektifitas pajak hotel dan pajak restoran di Kota Bengkulu dari tahun 2015 sampai dengan tahun 2018 cukup efektif, berkisar antara 80\% sampai $82 \%$. Sedangkan kontribusi penerimaan pajak hotel dan pajak restoran dari tahun 2015 sampai dengan tahun 2018 sangat mempunyai kontribusi dimana rata-rata setiap tahunnya mempunyai kontribusi diatas $4 \%$. Hal ini menunjukkan bahwa pendapatan asli daerah Kota Bengkulu dipengaruhi oleh proporsi yang besar dari pajak hotel dan pajak restoran. 


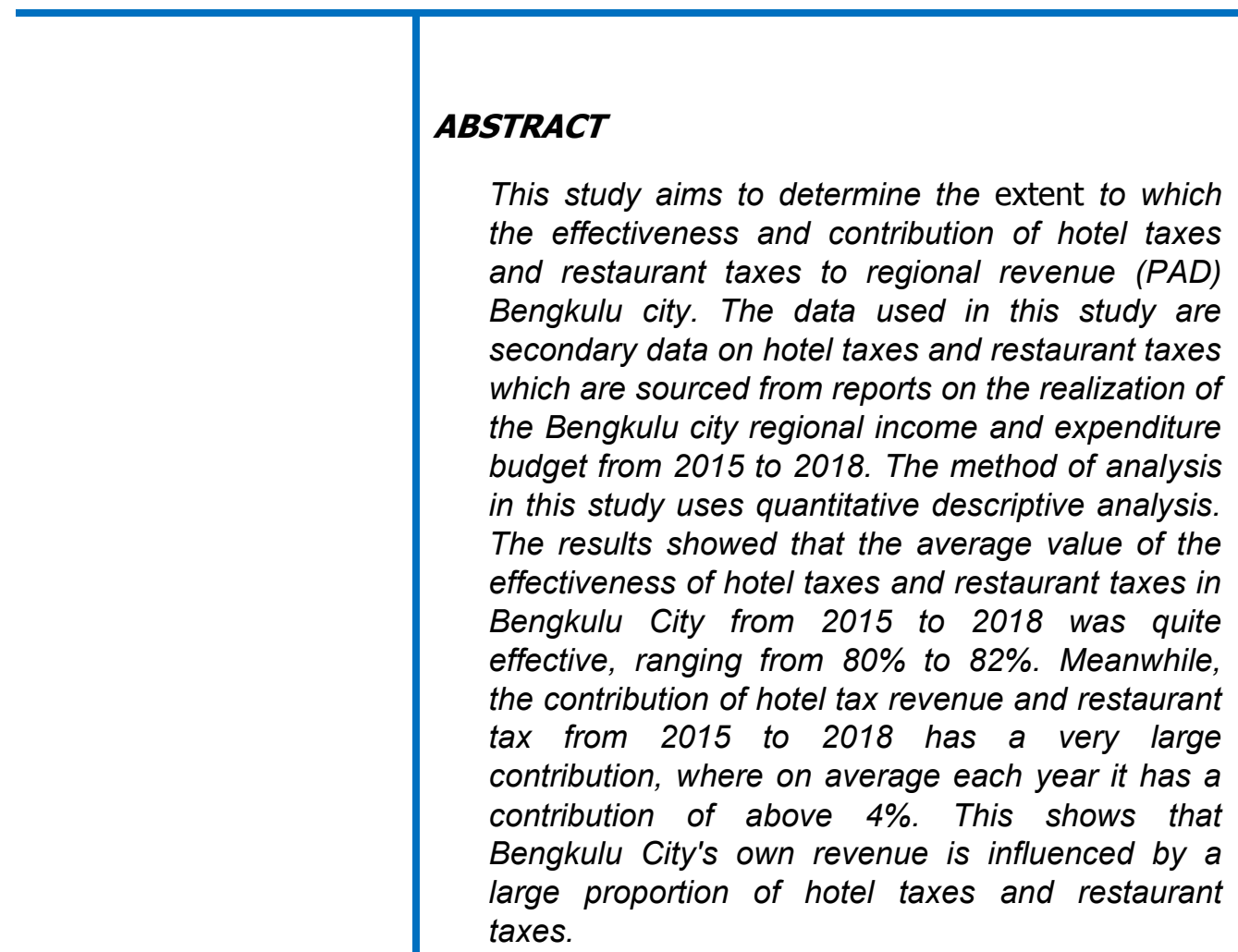

\section{PENDAHULUAN}

Pemberlakuan sistem desentralisasi oleh pemerintah pusat membuat daerahdaerah mempunyai kewenangan yang lebih untuk mengatur daerahnya sendiri. Pemerintah daerah berlomba untuk menunjukkan kepada pemerintah pusat bahwa mereka mampu untuk mengembangkan perekonomian di daerahnya sendiri. Salah satu tolak ukur untuk mengembangkan perekonomian didaerahnya, pemerintah daerah harus mampu untuk membiayai kebutuhan daerahnya secara mandiri yang berasal dari Pendapatan asli daerahnya (PAD) sendiri.

Menurut Mardiasmo (2002), Pendapatan Asli Daerah adalah penerimaan yang diperoleh dari sektor pajak daerah, retribusi daerah, hasil perusahaan milik daerah, hasil pengelolaan kekayaan daerah yang dipisahkan, dan lain-lain pendapatan asli daerah yang sah. Menurut Halim (2012), Pendapatan Asli Daerah (PAD) adalah "semua penerimaan daerah yang berasal dari sumber ekonomi asli daerah". Dapat disimpulkan bahwa Pendapatan Asli Daerah (PAD) adalah segenap pemasukan atau penerimaan yang masuk ke dalam kas daerah, diperoleh dari sumber-sumber dalam wilayahnya sendiri, dipungut berdasarkan Peraturan Daerah sesuai peraturan perundang-undangan yang berlaku dan dipergunakan untuk keperluan daerah.

Kota Bengkulu merupakan salah satu kota tujuan wisata di Indonesia. Dimana di Kota Bengkulu ini banyak sekali tempat wisata yang bisa menarik hati para wisawatawan untuk berkunjung kesini. Dimulai dari wisata rumah pengasingan bung 
karno, rumah fatmawati, benteng marlborought, pantai panjang dan masih banyak wisata lainnya. Banyaknya potensi wisata ini harusnya bisa dimanfaatkan oleh pemerintah kota Bengkulu untuk menggenjot kenaikan pendapatan asli daerah yang berasal dari wisatawan yang berkunjung ke Bengkulu ini. Dengan banyaknya wisatawan yang datang tentunya akan menambah tingkat hunian hotel dan wisatawan biasanya mencari kuliner daerah yang bisa dimanfaatkan oleh pemilik-pemilik restoran untuk menyediakan makanan khas bengkulu untuk para wisatawan.

Bergeraknya roda perekonomian yang diakibatkan oleh banyaknya wisatawan yang datang dapat meningkatkan pendapatan pengusaha hotel dan pengusaha restoran. Hal ini juga berdampak terhadap pemasukan pajak hotel dan pajak restoran bagi pemerintah kota Bengkulu sehingga pajak hotel dan pajak restoran bisa dijadikan salah satu penopang peningkatan Pendapatan asli daerah (PAD) Kota Bengkulu. Berdasarkan UU no. 28 tahun 2009 ada sebelas jenis pajak yang menjadi pajak kabupaten/kota, dua diantaranya adalah pajak hotel dan pajak restoran. Kota Bengkulu sebagai salah satu kota tujuan wisata harusnya bisa memanfaatkan potensi pajak hotel dan pajak restoran ini untuk meningkatkan penerimaan pendapatan asli daerah (PAD) Kota Bengkulu.

\section{LANDASAN TEORI}

\section{Pajak}

Pajak adalah iuran rakyat kepada kas Negara berdasarkan Undang- undang (yang dapat dipaksakan) dengan tidak mendapat jasa timbal (kontra prestasi) yang langsung dapat ditujukkan dan dengan digunakan untuk membayar pengeluaran umum (Mardiasmo, 2013). Pajak adalah pungutan wajib dari rakyat untuk negara. Setiap sen uang pajak yang dibayarkan rakyat akan masuk dalam pos pendapatan negara dari sektor pajak. Penggunaannya untuk membiayai belanja pemerintah pusat maupun daerah demi kesejahteraan masyarakat. Uang pajak digunakan untuk kepentingan umum, bukan untuk kepentingan pribadi. Pajak merupakan salah satu sumber dana pemerintah untuk mendanai pembangunan di pusat dan daerah, seperti membangun fasilitas umum, membiayai anggaran kesehatan dan pendidikan, dan kegiatan produktif lain. Pemungutan pajak dapat dipaksakan karena dilaksanakan berdasarkan undangundang.

\section{Pajak Hotel}

Pajak hotel adalah pajak yang dipungut oleh pemerintahan daerah, baik Kabupaten/Kota. Berdasarkan Undang-undang No. 28 Tahun 2009 Pasal 1, Objek pajak hotel adalah pelayanan yang disediakan oleh hotel dengan pembayaran, termasuk jasa penunjang sebagai kelengkapan hotel yang sifatnya memberikan kemudahan dan kenyamanan, termasuk fasilitas olahraga dan hiburan. Di Kota Bengkulu pajak hotel ditetapkan oleh peraturan daerah (PERDA) No. 09 Tahun 2011 dengan tarif 10\%. 


\section{Pajak Restoran}

Berdasarkan Undang-Undang No. 28 Tahun 2009 Pasal 1 angka 22 dan 23, pajak restoran adalah pajak atas pelayanan yang disediakan oleh hotel. Menurut UndangUndang Republik Indonesia No. 28 Tahun 2009 Tentang Pajak dan Retribusi Daerah pada pasal 37 yang menjelaskan bahwa objek pajak restoran adalah pelayanan yang disediakan oleh restoran, pelayanan yang disediakan oleh restoran sebagaimana yang dimaksud pada ayat 1 yang meliputi pelayanan penjualan makanan dan/atau minuman yang dikonsumsi oleh pembeli, baik yang dikonsumsi di tempat maupun di tempat lainnya. Di Kota Bengkulu pajak hotel ditetapkan oleh peraturan daerah (PERDA) No. 10 Tahun 2011 dengan tarif 10\%.

\section{Pendapatan Asli Daerah (PAD)}

Merujuk pasal 1 angka 18 Undang-undang Nomor 33 tahun 2004, Pendapatan asli daerah (PAD) adalah pendapatan yang diperoleh daerah yang dipungut berdasarkan peraturan daerah sesuai dengan peraturan perundang-undangan. Pendapatan asli daerah (PAD) merupakan perwujudan dari asas desentralisasi dan menjadi salah satu sumber pendapatan daerah. Sumber pertama dari Pendapatan asli daerah (PAD) adalah pajak daerah seperti Pajak Hotel dan Pajak Restoran.

\section{Efektifitas}

Efektifitas pada dasarnya mengacu pada sebuah keberhasilan atau pencapaian tujuan. Efektivitas merupakan salah satu dimensi dari produktivitas, yaitu mengarah kepada pencapaian untuk kerja yang maksimal, yaitu pencapaian target yang berkaitan dengan kualitas, kuantitas dan waktu.

\section{Kontribusi}

Kontribusi berasal dari bahasa inggris yaitu contribute, contribution, maknanya adalah keikutsertaan, keterlibatan, melibatkan diri maupun sumbangan. Berarti dalam hal ini kontribusi dapat berupa materi atau tindakan. Dalam penelitian ini kontribusi berarti sumbangan angka yang didapat dari pajak hotel dan restoran dalam rangka meningkatkan pendapatan asli daerah (PAD) Kota bengkulu.

\section{METODE PENELITIAN}

\section{Jenis dan Metode Pengumpulan Data}

Dalam penelitian ini jenis penelitian yang digunakan adalah jenis penelitian kuantitatif. Untuk jenis data yang digunakan dalam penelitian ini adalah data sekunder berupa pajak hotel dan pajak restoran yang bersumber dari laporan realisasi anggaran pendapatan dan belanja daerah Pemerintah Kota Bengkulu tahun 2015 sampai dengan 2018. 


\section{Metode Analisis}

\section{Analisis Efektifitas}

Analisis Efektifitas ini membandingkan antara realisasi dari penerimaan pajak hotel dan pajak restoran terhadap target yang telah ditetapkan.

$$
\begin{aligned}
& \text { Efektifitas Pajak Hotel }=\frac{\text { Realisasi Penerimaan Pajak Hotel }}{\text { Target penerimaan Pajak Hotel }} \times 100 \% \\
& \text { Efektifitas Pajak Restoran }=\frac{\text { Realisasi Penerimaan Pajak Restoran }}{\text { Target penerimaan Pajak Restoran }} \times 100 \%
\end{aligned}
$$

Tabel 1. Karakteristik efektivitas pajak hotel dan pajak restoran

\begin{tabular}{|c|c|}
\hline Presentase & Kriteria \\
\hline$>100 \%$ & Sangat Efektif \\
$>90-100 \%$ & Efektif \\
$>80-90 \%$ & Cukup Efektif \\
$>60-80 \%$ & Kurang Efektif \\
$<60 \%$ & Tidak Efektif \\
\hline
\end{tabular}

\section{Analisis Kontribusi}

Analisis kontribusi yaitu suatu alat analisis yang digunakan untuk mengetahui seberapa besar kontribusi dari pajak hotel dan pajak restoran terhadap total Pendapatan Asli Daerah (PAD), maka dibandingkanlah antara realisasi penerimaan pajak hotel dan pajak restoran terhadap total Pendapatan Asli Daerah (PAD).

$$
\text { Kontribusi Pajak Hotel } \quad=\frac{\text { Realisasi Penerimaan Pajak Hotel }}{\text { Total PAD }} \times 100 \%
$$

$$
\text { Kontribusi Pajak Restoran }=\frac{\text { Realisasi Penerimaan Pajak Restoran }}{\text { Total } P A D} \times 100 \%
$$


Tabel 2. Karakteristik kontribusi pajak hotel dan pajak restoran

\begin{tabular}{|c|c|}
\hline Presentase & Kriteria \\
\hline$>4 \%$ & Sangat mempunyai kontribusi \\
$3 \%-3,9 \%$ & Mempunyai kontribusi \\
$2 \%-2,9 \%$ & Cukup mempunyai kontribusi \\
$0,6 \%-1,9 \%$ & Kurang mempunyai kontribusi \\
$0 \%-0,5 \%$ & Tidak mempunyai kontribusi \\
\hline
\end{tabular}

\section{HASIL DAN PEMBAHASAN}

\section{Pembahasan}

\section{Analisis Perhitungan Efektifitas Pajak Hotel}

Tabel 3. Perhitungan efektifitas pajak hotel Kota Bengkulu Tahun 2015-2018:

\begin{tabular}{|l|l|c|c|c|}
\hline Tahun & $\begin{array}{c}\text { Target Penerimaan } \\
\text { Pajak Hotel (Rp) }\end{array}$ & $\begin{array}{c}\text { Realisasi } \\
\text { Penerimaan } \\
\text { Pajak Hotel (Rp) }\end{array}$ & $\begin{array}{c}\text { Tingkat } \\
\text { Efektifitas (\%) }\end{array}$ & Kategori \\
\hline 2015 & 6.004 .000 .000 & 4.746 .407 .673 & 79,05 & Kurang Efektif \\
\hline 2016 & 8.579 .000 .000 & 6.609 .436 .593 & 77,04 & Kurang Efektif \\
\hline 2017 & 9.000 .000 .000 & 7.430 .659 .732 & 82,56 & Cukup Efektif \\
\hline 2018 & 9.000 .000 .000 & 8.164 .142 .352 & 90,71 & Efektif \\
\hline
\end{tabular}

Sumber: laporan realisasi anggaran pendapatan dan belanja daerah Kota Bengkulu tahun 2015 sampai dengan 2018 (Data diolah)

Berdasarkan tabel diatas, dapat kita lihat tahun 2015 realisasi penerimaan pajak hotel sebesar Rp 4.746.407.673 dari target yang telah ditetapkan sebesar Rp 6.004.000.000, sehingga dapat kita lihat efektifitas pajak hotel pada tahun 2015 sebesar 79,05\% dan termasuk kategori kurang efektif. Pada tahun 2016 realisasi penerimaan pajak hotel sebesar Rp 6.609.436.593 dari target yag telah ditetapkan sebesar Rp 8.579.000.000, sehingga dapat kita lihat efektifitas pajak hotel pada tahun 2016 sebesar 77,04\% dan termasuk kategori kurang efektif. Pada tahun 2017 realisasi penerimaan pajak hotel sebesar Rp 7.430.659.732 dari target yag telah ditetapkan sebesar Rp 9.000.000.000, sehingga dapat kita lihat efektifitas pajak hotel pada tahun 2017 sebesar 82,56\% dan termasuk kategori cukup efektif. Pada tahun 2018 realisasi penerimaan pajak hotel sebesar Rp 8.164.142.352 dari target yag telah ditetapkan sebesar Rp 9.000.000.000, sehingga dapat kita lihat efektifitas pajak hotel pada tahun 2018 sebesar 90,71\% dan termasuk kategori efektif.

Secara umum, Pajak Hotel yang dikelola oleh pemerintah Kota Bengkulu ini belum bisa mencapai kategori sangat efektif yaitu realisasi pajak hotel mencapai nilai 
$100 \%$ dari target yang telah ditetapkan. Tetapi jika kita melihat tabel diatas terjadi kenaikan efektifitas yang signifikan dari tahun 2015 dan 2016 diangka 79,05\% dan 77,04\% kategori kurang efektif menjadi 82,56\% di tahun 2017 kategori cukup efektif dan kembali naik lagi menjadi 90,71\% di tahun 2018 kategori efektif. Hal ini menunjukkan bahwa pemerintah Kota Bengkulu telah berhasil meningkatkan pendapatan dari pajak hotel setiap tahunnya, dan tidak menutup kemungkinan pada tahun-tahun selanjutnya akan mencapai kategori sangat efektif dengan pencapaian diatas $100 \%$.

\section{Analisis Perhitungan Efektifitas Pajak Restoran}

Tabel 4. Perhitungan efektifitas pajak restoran Kota Bengkulu Tahun 2015-2018:

\begin{tabular}{|c|l|c|c|c|}
\hline Tahun & $\begin{array}{c}\text { Target Penerimaan } \\
\text { Pajak Restoran } \\
(\text { Rp) }\end{array}$ & $\begin{array}{c}\text { Realisasi } \\
\text { Penerimaan Pajak } \\
\text { Restoran (Rp) }\end{array}$ & $\begin{array}{c}\text { Tingkat } \\
\text { Efektifitas } \\
(\%)\end{array}$ & Kategori \\
\hline 2015 & 6.374 .736 .000 & 5.477 .097 .152 & 85,92 & Cukup Efektif \\
\hline 2016 & 8.800 .000 .000 & 6.582 .648 .814 & 74,80 & Kurang Efektif \\
\hline 2017 & 9.000 .000 .000 & 7.347 .723 .851 & 81,64 & Cukup Efektif \\
\hline 2018 & 9.000 .000 .000 & 7.174 .613 .324 & 79,72 & Kurang Efektif \\
\hline
\end{tabular}

Sumber: laporan realisasi anggaran pendapatan dan belanja daerah Kota Bengkulu tahun 2015 sampai dengan 2018 (Data diolah)

Berdasarkan tabel diatas, dapat kita lihat tahun 2015 realisasi penerimaan pajak restoran sebesar Rp 5.477.097.152 dari target yang telah ditetapkan sebesar Rp 6.374.736.000, sehingga dapat kita lihat efektifitas pajak restoran pada tahun 2015 sebesar 85,92\% dan termasuk kategori cukup efektif. Pada tahun 2016 realisasi penerimaan pajak restoran sebesar Rp 6.582.648.814 dari target yag telah ditetapkan sebesar Rp 8.800.000.000, sehingga dapat kita lihat efektifitas pajak restoran pada tahun 2016 sebesar 74,80\% dan termasuk kategori kurang efektif. Pada tahun 2017 realisasi penerimaan pajak restoran sebesar Rp 7.347.723.851 dari target yag telah ditetapkan sebesar Rp 9.000.000.000, sehingga dapat kita lihat efektifitas pajak restoran pada tahun 2017 sebesar 81,64\% dan termasuk kategori cukup efektif. Pada tahun 2018 realisasi penerimaan pajak restoran sebesar Rp 7.174.613.324 dari target yag telah ditetapkan sebesar Rp 9.000.000.000, sehingga dapat kita lihat efektifitas pajak restoran pada tahun 2018 sebesar 79,72\% dan termasuk kategori kurang efektif.

Secara umum, Pajak Restoran yang dikelola oleh pemerintah Kota Bengkulu ini belum bisa mencapai kategori sangat efektif yaitu realisasi pajak hotel mencapai nilai $100 \%$ dari target yang telah ditetapkan dan cenderung Fluktuatif. Pada tahun 2015, tingkat efektifitas 85,92\% kategori cukup efektif turun menjadi 74,80\% kategori kurang efektif meskipun realisasi pendapatannya bertambah dari Rp 5.477.097.152 naik menjadi Rp 6.582.648.814. Pada tahun 2017 kembali naik 81,64\% kategori cukup efektif, tetapi tahun 2018 kembali turun 79,72\% kategori kurang efektif dan realisasinya pun juga turun dari Rp 7.347.723.851 pada tahun 2017 turun menjadi Rp 7.174.613.324 pada tahun 2018. Hal ini menunjukkan bahwa pemerintah Kota 
Bengkulu harus lebih selektif lagi dalam menetapkan target penerimaan pajak restoran dengan melihat sumber-sumber pendapatannya sehingga realisasi penerimaan pajak restoran nanti benar-benar bisa tercapai sesuai dengan target yang telah ditetapkan.

\section{Analisis Perhitungan Kontribusi Pajak Hotel terhadap penerimaan Pendapatan Asli Daerah (PAD)}

Besarnya kontribusi penerimaan pajak hotel terhadap Pendapatan Asli Daerah (PAD) Kota Bengkulu dihitung dengan membandingkan realisasi penerimaan pajak hotel dengan total realisasi penerimaan Pendapatan Asli Daerah (PAD). Pada tabel dibawah ini disajikan hasil perhitungan kontribusi penerimaan pajak hotel terhadap Pendapatan Asli Daerah (PAD) Kota Bengkulu tahun 2015 sampai dengan tahun 2018:

Tabel 5. hasil perhitungan kontribusi penerimaan pajak hotel terhadap Pendapatan Asli Daerah (PAD) Kota Bengkulu tahun 2015 - 2018

\begin{tabular}{|l|l|c|c|c|}
\hline Tahun & $\begin{array}{c}\text { Realisasi } \\
\text { Penerimaan Pajak } \\
\text { Hotel (Rp) }\end{array}$ & $\begin{array}{c}\text { Total Realisasi } \\
\text { Penerimaan Pendapatan } \\
\text { Asli Daerah (PAD) }\end{array}$ & $\begin{array}{c}\text { Tingkat } \\
\text { Kontribusi (\%) }\end{array}$ & Kategori \\
\hline 2015 & 4.746 .407 .673 & 56.867 .738 .138 & 8,35 & $\begin{array}{l}\text { Sangat } \\
\text { mempunyai } \\
\text { kontribusi }\end{array}$ \\
\hline 2016 & 6.609 .436 .593 & 63.222 .067 .036 & 10,45 & $\begin{array}{l}\text { Sangat } \\
\text { mempunyai } \\
\text { kontribusi }\end{array}$ \\
\hline 2017 & 7.430 .659 .732 & 75.071 .261 .712 & 9,90 & $\begin{array}{l}\text { Sangat } \\
\text { mempunyai } \\
\text { kontribusi }\end{array}$ \\
\hline 2018 & 8.164 .142 .352 & 63.722 .670 .442 & 12,81 & $\begin{array}{l}\text { Sangat } \\
\text { mempunyai } \\
\text { kontribusi }\end{array}$ \\
\hline
\end{tabular}

Sumber: laporan realisasi anggaran pendapatan dan belanja daerah Kota Bengkulu tahun 2015 sampai dengan 2018 (Data diolah)

Berdasarkan tabel diatas, pada tahun 2015 realisasi penerimaan Pendapatan Asli daerah (PAD) Rp 56.867.738.138 dan realisasi penerimaan pajak hotel Rp 4.746.407.673 sehingga diperoleh besarnya kontribusi penerimaan pajak hotel terhadap total penerimaan Pendapatan Asli daerah (PAD) tahun 2015 sebesar 8,35\% yang artinya pajak hotel ini sangat mempunyai kontribusi bagi penerimaan Pendapatan Asli daerah (PAD) Kota Bengkulu karena tingkat kontribusinya diatas 4\%. Pada tahun 2016, realisasi penerimaan Pendapatan Asli daerah (PAD) Rp 63.222.067.036 dan realisasi penerimaan pajak hotel $\mathrm{Rp}$ 6.609.436.593 sehingga diperoleh besarnya kontribusi penerimaan pajak hotel terhadap total penerimaan Pendapatan Asli daerah (PAD) tahun 2016 sebesar 10,45\% yang artinya pajak hotel ini sangat mempunyai kontribusi bagi penerimaan Pendapatan Asli daerah (PAD) Kota Bengkulu karena tingkat kontribusinya diatas 4\%. Pada tahun 2017, realisasi penerimaan Pendapatan Asli daerah (PAD) Rp 75.071.261.712 dan realisasi penerimaan pajak hotel Rp 7.430.659.732 sehingga diperoleh besarnya kontribusi penerimaan pajak hotel terhadap total penerimaan Pendapatan Asli daerah (PAD) tahun 2017 sebesar 9,90\% 
yang artinya pajak hotel ini sangat mempunyai kontribusi bagi penerimaan Pendapatan Asli daerah (PAD) Kota Bengkulu karena tingkat kontribusinya diatas 4\%. Pada tahun 2018, realisasi penerimaan Pendapatan Asli daerah (PAD) Rp 63.722.670.442 dan realisasi penerimaan pajak hotel Rp 8.164.142.352 sehingga diperoleh besarnya kontribusi penerimaan pajak hotel terhadap total penerimaan Pendapatan Asli daerah (PAD) tahun 2018 sebesar 12,81\% yang artinya pajak hotel ini sangat mempunyai kontribusi bagi penerimaan Pendapatan Asli daerah (PAD) Kota Bengkulu karena tingkat kontribusinya diatas 4\%.

Hasil penelitian ini menunjukkan bahwa kontribusi penerimaan pajak hotel di Kota Bengkulu terhadap penerimaan Pendapatan Asli daerah (PAD) selama empat tahun dari tahun 2015 sampai dengan tahun 2018 menunjukkan proporsi yang besar dan kontribusi yang tinggi, dimana setiap tahunnya pajak hotel ini memberikan kontribusi selalu diatas $4 \%$ yang artinya sangat mempunyai kontribusi. Hasil penelitian ini juga menunjukkan bahwa pajak hotel adalah satu satu pajak daerah yang potensial di kota bengkulu yang harus dijaga dan ditingkatkan pendapatannya agar selalu menjadi penopang dan penyumbang kontribusi yang tinggi bagi Pendapatan Asli daerah (PAD) Kota Bengkulu.

\section{Analisis Perhitungan Kontribusi Pajak Restoran terhadap penerimaan Pendapatan Asli Daerah (PAD)}

Tabel 6. Hasil perhitungan kontribusi penerimaan pajak restoran terhadap Pendapatan Asli Daerah (PAD) Kota Bengkulu tahun 2015 - 2018

\begin{tabular}{|l|c|c|c|l|}
\hline Tahun & $\begin{array}{c}\text { Realisasi } \\
\text { Penerimaan } \\
\text { Pajak Restoran } \\
\text { (Rp) }\end{array}$ & $\begin{array}{c}\text { Total Realisasi } \\
\text { Penerimaan } \\
\text { Pendapatan Asli } \\
\text { Daerah (PAD) }\end{array}$ & $\begin{array}{c}\text { Tingkat } \\
\text { Kontribusi (\%) }\end{array}$ & Kategori \\
\hline 2015 & 5.477 .097 .152 & 56.867 .738 .138 & 9,63 & $\begin{array}{l}\text { Sangat } \\
\text { mempunyai } \\
\text { kontribusi }\end{array}$ \\
\hline 2016 & 6.582 .648 .814 & 63.222 .067 .036 & 10,41 & $\begin{array}{l}\text { Sangat } \\
\text { mempunyai } \\
\text { kontribusi }\end{array}$ \\
\hline 2017 & 7.347 .723 .851 & 75.071 .261 .712 & 9,79 & $\begin{array}{l}\text { Sangat } \\
\text { mempunyai } \\
\text { kontribusi }\end{array}$ \\
\hline 2018 & 7.174 .613 .324 & 63.722 .670 .442 & 11,26 & $\begin{array}{l}\text { Sangat } \\
\text { mempunyai } \\
\text { kontribusi }\end{array}$ \\
\hline
\end{tabular}

Sumber: laporan realisasi anggaran pendapatan dan belanja daerah Kota Bengkulu tahun 2015 sampai dengan 2018 (Data diolah)

Berdasarkan tabel diatas, pada tahun 2015 realisasi penerimaan Pendapatan Asli daerah (PAD) Rp 56.867.738.138 dan realisasi penerimaan pajak restoran Rp 5.477.097.152 sehingga diperoleh besarnya kontribusi penerimaan pajak restoran terhadap total penerimaan Pendapatan Asli daerah (PAD) tahun 2015 sebesar 9,63\% yang artinya pajak restoran ini sangat mempunyai kontribusi bagi penerimaan Pendapatan Asli daerah (PAD) Kota Bengkulu karena tingkat kontribusinya diatas 4\%. 
Pada tahun 2016, realisasi penerimaan Pendapatan Asli daerah (PAD) Rp 63.222.067.036 dan realisasi penerimaan pajak restoran Rp 6.582.648.814 sehingga diperoleh besarnya kontribusi penerimaan pajak restoran terhadap total penerimaan Pendapatan Asli daerah (PAD) tahun 2016 sebesar 10,41\% yang artinya pajak restoran ini sangat mempunyai kontribusi bagi penerimaan Pendapatan Asli daerah (PAD) Kota Bengkulu karena tingkat kontribusinya diatas 4\%. Pada tahun 2017, realisasi penerimaan Pendapatan Asli daerah (PAD) Rp 75.071.261.712 dan realisasi penerimaan pajak restoran Rp 7.347.723.851 sehingga diperoleh besarnya kontribusi penerimaan pajak restoran terhadap total penerimaan Pendapatan Asli daerah (PAD) tahun 2017 sebesar 9,79\% yang artinya pajak restoran ini sangat mempunyai kontribusi bagi penerimaan Pendapatan Asli daerah (PAD) Kota Bengkulu karena tingkat kontribusinya diatas 4\%. Pada tahun 2018, realisasi penerimaan Pendapatan Asli daerah (PAD) Rp 63.722.670.442 dan realisasi penerimaan pajak restoran Rp 7.174.613.324 sehingga diperoleh besarnya kontribusi penerimaan pajak restoran terhadap total penerimaan Pendapatan Asli daerah (PAD) tahun 2018 sebesar 11,26\% yang artinya pajak restoran ini sangat mempunyai kontribusi bagi penerimaan Pendapatan Asli daerah (PAD) Kota Bengkulu karena tingkat kontribusinya diatas $4 \%$.

Hasil penelitian ini menunjukkan bahwa kontribusi penerimaan pajak restoran di Kota Bengkulu terhadap penerimaan Pendapatan Asli daerah (PAD) selama empat tahun dari tahun 2015 sampai dengan tahun 2018 menunjukkan proporsi yang besar dan kontribusi yang tinggi, dimana setiap tahunnya pajak restoran ini memberikan kontribusi selalu diatas $4 \%$ yang artinya sangat mempunyai kontribusi. Hasil penelitian ini juga menunjukkan bahwa pajak restoran adalah satu satu pajak daerah yang potensial di kota bengkulu yang harus dijaga dan ditingkatkan pendapatannya agar selalu menjadi penopang dan penyumbang kontribusi yang tinggi bagi Pendapatan Asli daerah (PAD) Kota Bengkulu.

\section{KESIMPULAN DAN SARAN}

\section{Kesimpulan}

Berdasarkan hasil penelitian yang dilakukan, maka dapat ditarik kesimpulan Efektifitas Pajak Hotel di Kota Bengkulu periode tahun 2015-2018 belum maksimal. Tahun 2015 efektifitasnya 79,05\% kategori kurang efektif, tahun 2016 efektifitasnya 77,04\% kategori kurang efektif, tahun 2017 efektifitasnya 82,56\% kategori cukup efektif dan tahun 2018 efektifitasnya 90,71\% kategori efektif. Walaupun belum maksimal secara efektifitas, angka pemasukan pajak hotel dari tahun 2015-2018 terus naik dimulai dari Rp 4.746.407.673 pada tahun 2015 naik menjadi Rp 6.609.436.593 pada tahun 2016. Tahun 2017 kembali mengalami kenaikan menjadi Rp 7.430.659.732 dan tahun 2018 naik kembali menjadi Rp 8.164.142.352. Efektifitas Pajak Restoran di Kota Bengkulu periode tahun 2015-2018 belum maksimal dan cenderung naik turun (fluktuatif). Tahun 2015 efektifitasnya 85,92\% kategori cukup efektif, tahun 2016 efektifitasnya 74,80\% kategori kurang efektif, tahun 2017 efektifitasnya 81,64\% kategori cukup efektif dan tahun 2018 efektifitasnya 79,72\% kategori kurang efektif. Tren efektifitas pajak restoran ini tidak sebagus tren pajak hotel yang mengalami kenaikan dari tahun ke tahun. Tahun 2015 Angka pemasukan pajak restoran Rp 5.477.097.152 dan mengalami kenaikan pada tahun 2016 menjadi Rp 6.582.648.814. Tahun 2017 kembali naik menjadi Rp 7.347.723.851. tetapi tahun 2018 mengalami 
penurunan menjadi Rp 7.174.613.324. Kontribusi Pajak Hotel dan Pajak Restoran di Kota Bengkulu periode tahun 2015-2018 termasuk kategori sangat mempunyai kontribusi dimana setiap tahunnya realisasi pajak hotel dan pajak restoran terhadap Pendapatan Asli Daerah (PAD) selalu diatas 4\%. Hal ini menunjukkan bahwa pajak hotel dan pajak restoran mempunyai komposisi yang besar dalam menyumbang angka di Pendapatan Asli Daerah (PAD) Kota Bengkulu.

\section{Saran}

1. Pemerintah Kota Bengkulu melalui Dinas Pendapatan Daerah lebih selektif lagi dalam menentukan target penerimaan pajak hotel dan pajak restoran. Ketika akan membuat target, dipastikan sumber pajaknya jelas dan terukur sehingga antara target yang telah ditetapkan dengan realisasi penerimaan pajaknya tidak terjadi kesenjangan gap yang terlalu jauh sehingga efektifitas itu akan tercapai.

2. Pemerintah Kota Bengkulu terus menjaga keberlangsungan penerimaan pajak hotel dan pajak restoran di Kota Bengkulu dengan terus menjaga hubungan baik bersama pengusaha hotel dan pengusaha restoran, karena kedua jenis pajak daerah ini memiliki kontribusi yang tinggi dalam penerimaan Pendapatan Asli Daerah (PAD) Kota Bengkulu.

\section{DAFTAR PUSTAKA}

Halim, Abdul. 2012. Akuntansi Keuangan Daerah Edisi 04. Jakarta: Salemba Empat

Harun. (2014). Analisis Potensi Pajak Hotel dan Pajak Restoran dan Kontribusinya terhadap Pendapatan Asli Daerah (PAD) (Studi Kasus pada Dinas Pendapatan Daerah Kota Batu Tahun 2011-2013). Jurnal Administrasi Bisnis S1 Universitas Brawijaya, 14(1).

Indrianto., S. (2011). Analisis Kontribusi Pajak Hotel Terhadap Pendapatan Asli Daerah (Pad) Di Kota Manado. 1(3), 722-729

Kota Bengkulu. Peraturan Daerah Kota Bengkulu Nomor 09 Tahun 2011 Tentang Pajak Hotel.

Kota Bengkulu. Peraturan Daerah Kota Bengkulu Nomor 10 Tahun 2011 Tentang Pajak Restoran.

Mardiasmo. 2013. Perpajakan Edisi Revisi. Yogyakarta: Andi Publisher

Suwarno, A. E., \& Suhartiningsih, S. (2016). Efektifitas Evaluasi Potensi Pajak Daerah Sebagai Sumber Pendapatan Asli Daerah. Riset Akuntansi Dan Keuangan Indonesia, 7(2), 162-173. https://doi.org/10.23917/reaksi.v7i2.2615

Undang-Undang Republik Indonesia Nomor 28 Tahun 2009. Pajak Daerah dan Retribusi Daerah. 15 September 2009. Lembaran Negara Republik Indonesia Tahun 2009 Nomor 130 Jakarta

Undang-Undang Republik Indonesia Nomor 32 Tahun 2004. Pemerintah Daerah. 15 Oktober 2004. Lembaran Negara Republik Indonesia Tahun 2004 Nomor 125. Jakarta

Undang-Undang Republik Indonesia Nomor 33 Tahun 2004 Tentang Perimbangan Keuangan antara Pemerintah Pusat dan Pemerintah Daerah 
Yuliartini, P. I., \& Supadmi, N. L. (2015). Efektivitas Pemungutan Pajak Hotel dan Restoran pada Pemerintah Daerah Kota Denpasar. E Journal Akuntansi Udayana, 2, 489-502. 